\title{
CRISES OF REAL SECTOR AND FISCAL POLICIES IN TURKEY IN THE PROCESS OF GLOBALIZATION
}

\author{
İpek DOĞAN ÖZER ${ }^{1}$
}

\begin{abstract}
This study examines the crises, which increases in prevalence and spreadsalong with globalization, in terms of the fiscal policies implemented in the Turkish economy. The focus of the study is the impact of Mortgage crises on Turkey and the analysis of the 2018 real sector indicators in terms of the crisis.

Globalization has been on the rise since the 19th century. Liberal policies implemented with globalization creates new opportunities in some cases while these policies presents source of threat in some other cases. Economic crises are at the top of this threat. The dependence of the country's economy on the economies of other countries plays a significant role in the emergence of a crisis. This kind of dependency relation leads crises to spread rapidly to other country/ countries. It was the 24 January Decisions leading to this dependence and contagion for Turkish economy. Liberal policies led to ruleless and limitless flow of global capital specially in the short term and this made Turkish economy vulnerable to some risks. Due to these risks the structural problems of Turkey as the high share of debt interest in the budget, inflation, foreign trade deficit, current account deficit, unemployment etc. have continued. Sometimes in some sectors these structural problems have manifested themselves as a crisis.

The crisis arises in the financial and reel sectors. The economic crisis which is the focus of discussions in Turkey today will be analyzed in comparision with the 2008 crisis in terms of real sector. The current situation of the real sector will be revealed. Moreover, it will be discussed that the implemented monetary policies are insufficient and instead fiscal policies are more successful. Thus, it will be seen that in the 21th century the Keynesian policies are on the agenda again. The expected outcome of the study is observation of recession and inflation in the Turkish real sector.
\end{abstract}

Keywords: Economic Crisis, Real Sector, Fiscal Policy

JEL Code: G17, F38, E62.

\section{Introduction}

There is an undeniable effect of globalization both in Turkey and in the world. Through globalization, the world has shrunk and financial capital has gained a very fast and unlimited space of movement from one country to another. While unlimited and free circulation of the financial capital has a positive impact on the country where it enters as a resource, it may cause negative even destructive effects in the country it outflows.The leading effect is crisis which increase in prevalence and spreading with globalization.The global economic crises emerge in a specific country and spreads to the other country(s).

There have been a wide variety of crises in the globalization process. The emergence of crises, the affected area and the policies to be implemented have been differentiated within historical process. In the period when Classical Economic School was dominant, equilibrium was accepted as

\footnotetext{
1 Lecturer, Osmaniye Korkut Ata University, ipekdogan.04@hotmail.com
} 
the normal state of the economy and the state of imbalance is accepted as temporary. However, emergence of 1929 Great Depression totally destroyed this dominance. The crisis of 1929 was the first global crisis in the world. It was experienced due to printing unbacked money. Since the source of the crisis was money, the remedy to get rid of it was seen in the monetary policy. However, monetary policy did not solve the problem. On the other hand, it was understood that the state of imbalance in economy is not temporary and state intervention is compulsory. Keynesian demand-side policies came to the fore. In order to get out of the crisis, not only monetary policies but also fiscal policies started to be implemented.

After 1929 crisis, the largest scale global crisis that has devastating effects is the 2008 crisis that began in America and affected other countries. In the meantime, Keynesian policies, capitalist order, social state have begun to be discussed again. This study discusses the effects of 2008 crisis to Turkey, implemented fiscal policies and current real sector with using empirical data. The economic crises experienced in Turkish real sector between 2008-2009 is compared with 2018 data. The study searches an answer whether real sector experiences a crisis in 2018.

\section{The Impact of the Crises on Turkey That Began in US}

The largest scale crisis experienced during the globalization process is the Great Depression of 1929. 1929 crisis is significant in terms of its effects and consequences. Meantime it is understood that the state of imbalance is not temporary and state intervention is obligatory. Keynesian demand-side policies came to the fore due to the failure of Classical Economics in preventing crisis. Thus, not only monetary policies but also fiscal policies started to be implemented in order to get out of crisis.

Following 1929, the largest scale global crisis that has devastating effects emerged in US in 2008. Not only US but also other countries have significantly affected from 2008 crisis. The Federal Reserve (FED) has applied low interest rates that lead to emergence of new financial instruments. The search of capital for higher profits led him to these new fiscal instruments. Accordingly, a rapid increase in demand caused by lack of information about derivative markets and asymmetric information has increased the amount of product and the balloon has swelled (Eğilmez, 2009: 96).

Table 1. 2007 Global Capital Markets

\begin{tabular}{|l|c|c|c|}
\hline \multicolumn{1}{|c|}{ Billion USD } & GDP & $\begin{array}{c}\text { Foreign Exchange } \\
\text { Reserve }\end{array}$ & Stocks, Bonds Etc \\
\hline The World & 55.545 & 6.448 & 144.927 \\
\hline EU & 15.689 & 280 & 42.952 \\
\hline USA & 13.808 & 60 & 49.802 \\
\hline Japan & 4.382 & 953 & 13.882 \\
\hline Developing Countries & 17.282 & 4.910 & 28.771 \\
\hline
\end{tabular}

Source: Eğilmez, 2009: 45.

The global capital markets for 2007 are given in Table 1. While European Union (EU) has 15.689 billion dollars and United States (USA) has 13.808 billion dollars; developing countries have 17.282 billion dollars. EU and USA hold $53 \%$ of the world's gross domestic product (GDP). $29 \%$ of the stocks, and bonds and similar instruments are in the hand of EU and $34 \%$ are in the United States. It is seen that most of the derivative markets are in the USA. On the other hand, since 
financial markets are not well developed in developing countries, instruments like stock and bond are at a lower level. Since each crisis emerges as an outcome of growth, it is impressive that the size of the derivative market is 2.6 times of the world GDP which is 55 trillion dollars.

In the USA, especially low floating interest rates of mortgage loans in the housing finance system increased; and housing demand and housing prices rose. In conjunction with this artificial rise, people with subthreshold credit ratings have head for housing loans. Thus, prices in the housing market go up and a price bubble has formed. Due to the non-repayment of subthreshold loans in the US, banks reduced credit supply and the housing demand and housing prices decreased. The rapid decline in the prices of securities affected each country investing in this area. The crisis started in global money markets narrowed credit markets in US and Europe, stock prices declined, uncertainty and shortage of payment increased in the economy (Yilmaz, 2014: 117). The 2008 crisis emerged in the real estate sector in the USA affected other countries with the collapse of an investment bank named Lehman Brothers (Kazgan, 2013: 281-282).

Due to the fact the absence of development of Turkishderivatives market, Turkey did not directly affect by this crisis. Indirectly, the decrease in exports and foreign loans have affected the real sector in Turkey and led to the crisis. The inflow of funds decreased but the growth rate did not decrease in the first six months of 2008. Therefore, it was thought that Turkey was not affected by the crisis. However, all sectors except agriculture and finance experienced a collapse in the last quarter of 2008 (Kazgan, 2013: 280-283). The contraction of Turkish economy has led to an increase in budget deficit by reducing the tax base. Economic stability deteriorated due to the decrease of investment as an outcome of raise in public debt and risk premium (Yılmaz, 2014: 267-268).

Contraction in Turkish economy has continued in 2009, the current account deficit increased, foreign direct investment reduced and foreign capital has left the country. On the other hand, large companies internationalized and SMEs were closed (Kazgan, 2013: 285-288).

The reason behind the economic crisis was accepted as market and again state's weight and power in the economy were increased (Piketty, 2018: 510). In order to get out of the crisis, monetary policy implemented. However, when it was insufficient stimulative policies were applied. In fact, compared to fiscal policy monetary policy is easier in implementation. However, fiscal policies are more effective. Therefore, liquidity supports, tax incentives, loans for production and exports, warranty and funding supports have followed the monetary policy implemented by the Central Bank.Cash repatriation reduced withholding tax to zero that implemented to domestic investors in equity gains. Tax debts before September 1, 2008 were split into installments at 3\% interest for eighteen months. The deduction in resource utilization support fund in loans extended to real persons wasreduced to $10 \%$. The private communication tax of Internet service providers was reduced to $5 \%$. Corporate tax exemption was introduced for SMEs. SMEs were supported with zero or low interest loans. SMEs were also given opportunity to benefit from KOSGEB loans. The maturities of low-interest agricultural loans by Ziraat Bank and Agricultural Credit Cooperatives was increased. Eximbank's credit limits and issued capital was increased. In order to increase domestic demand, the period of temporary special consumption tax discount rates was extended in 2009.

In the Decision on State Aids in Investments accepted in 2009, customs tax exemption, minimum amount of investments, VAT exemption, employer's share of insurance premium, tax deduction 
and budgetary payments were arranged. Canalizing the focus on high value-added investments, preventing unemployment through increasing production, ensuring sustainable development, increasing the international competitiveness that encourage large-scale investments with high technology and research-development content, increasing foreign direct investments and reducing regional development differences were main targets of these applications. Within the scope of the notification published in accordance with this decision, incentive amounts for four investment regions and minimum investment amount to benefit from incentives were determined. Those who exceed the minimum amount of the investment have been provided with customs duty exemption, value added tax (VAT) exemption, tax deduction, investment site allocation and support for employer's national insurance contribution.

Global crisis had a negative impact on Turkish economy in terms of foreign trade, financing and expectations. The economy recovered an environment of trust with the monetary policy and following simulative packages. Accordingly, favorable credit conditions have increased domestic demand. Thus, the impact of the crisis on Turkish economy declined towards the end of 2009. The indicators of the crisis have disappeared with $11 \%$ growth in 2010 . As a result of the crisis, the role of the state in the economy (social state, increase in tax rates, progressive tax system etc.) had been re-questioned.

\section{Evaluation of $\mathbf{2 0 1 8}$ within the Scope of Real Sector Indicators}

For the first time since the 2008 global crisis, the world economy and global trade began to revive in 2017. Economic growth has accelerated in the US and Europe and unemployment rates have declined. On the other hand, raise in oil prices in developing countries led to increase in growth rates. In the Chinese economy, shadow banking and capital outflows began to be controlled, the financial sector was relieved. However, the tight monetary policy implemented by the American Central Bank (FED) and European Central Bank (ECB) had a negative impact on global capital flows. Countries with foreign currency debt got into a panic. In the meantime, Turkey increased industrial production capacity utilization rate up to $80 \%$ in 2017 . In order to reduce the budget deficit, the government has appealed to austerity measures. In addition, tax rates in some sectors were increased and new taxes were introduced (TÜSIAD, 2018: 3-17).

Turkey experienced a significant rise in exchange rates in the second quarter of 2018. Due to the rise in the exchange rate, demand for foreign currency also increased and Turkish Lira depreciated. Generally, a speculative attack on any currency causes a currency crisis (Krugman, 1997: 1). This crisis has prevented by implementation of the monetary policies. Since the effect of sudden and rapid rise in exchange rate experienced in 2018 has been observed in real sector, only real sector data are included. The crisis in the real sector shows itself in the form of unemployment, stagnation, inflation etc. in goods, services and labor markets. Two-quarter data is taken as basis to evaluate instability conditions such as inflation, stagflation and recession. An economy that has a growth rate of $0-2 \%$ within last six-month periodis considered to be in a recession period. If the growth is negative and continues to shrink, the recession is turning to a crisis (Ulusoy, 2016: 220).

In order to understand the situation in the real sector, growth rate, industrial production index, inflation, construction cost index and unemployment rate indicators will be used. While analyzing indicators, the comparison of 2008 and 2018 is significant to understand the current real sector situation better. 
Figure 1. Growth Rate (Change in GDP\%)

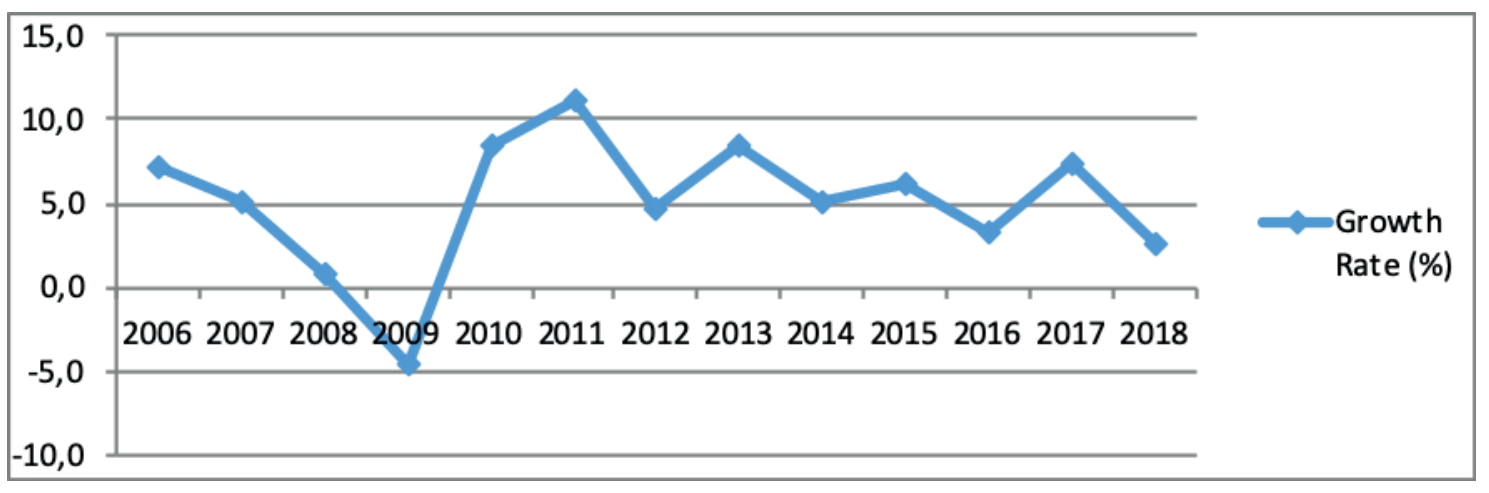

Source: Generated by the author using the TurkStat data.

The growth rate of Turkish economy between 2006- 2018 is shown in Figure 1. Figure 1 shows that the economy has shrank since 2006, the growth rate in 2008 is just $0,8 \%$ and the economy shrank by $4,7 \%$. It is seen that in Turkey the global economic crisis of 2008 shows its impact in 2009. The economy recovered in 2010 and the growth rate in 2011 was $11,1 \%$. However, the economy narrowed again in 2012 and grew by $8,5 \%$ in 2013 . The economy shrank compared to the previous year in 2014. It grew by 6,1\% in 2015, shrunk again in 2016 and the growth rate in 2017 was 7,4\%. It is seen that Turkish economy cannot sustained a steady growth at that time. In September 2018, the economy contracted \%2,2 and regress to 5,2\%. The downturn experienced in 2008 and 2009 has not yet taken place in 2018. However, while the economy grew by $1,8 \%$ in the third quarter of 2018 , the economy shrank by $3 \%$ in the last quarter. For this reason, the economy has entered the recession process.

Table 2. 2018 GrossDomestic Product InTerms of TL/ USD

\begin{tabular}{|l|l|c|}
\hline 1. Quarter & 788billionTL & 206 billion \$* \\
\hline 2. Quarter & 885billion TL & 202 billion $\$$ \\
\hline 3. Quarter & 1.016 trillion TL & 180 billion $\$$ \\
\hline 4. Quarter & 1.010 trillion TL & 183 billion\$ \\
\hline
\end{tabular}

* Calculations were made on average three-month exchange rates.

Source: Generated by the author using TurkStat, Ministry of Treasury and Finance data.

As shown in Table 2, except last period Turkish per capita GDP at current prices rose in TL terms. However, due to the $3 \%$ contraction in the last quarter of the economy, the national income decreased in TL terms. However, the national income declined against the dollar except the last period. At this point, the appreciation of the Turkish lira is important (Eğilmez, Yeniçağ, 10.12.2018). 
Figure 2. Change Rate of Industrial Production Index Compared to December of the Previous Year(\%)

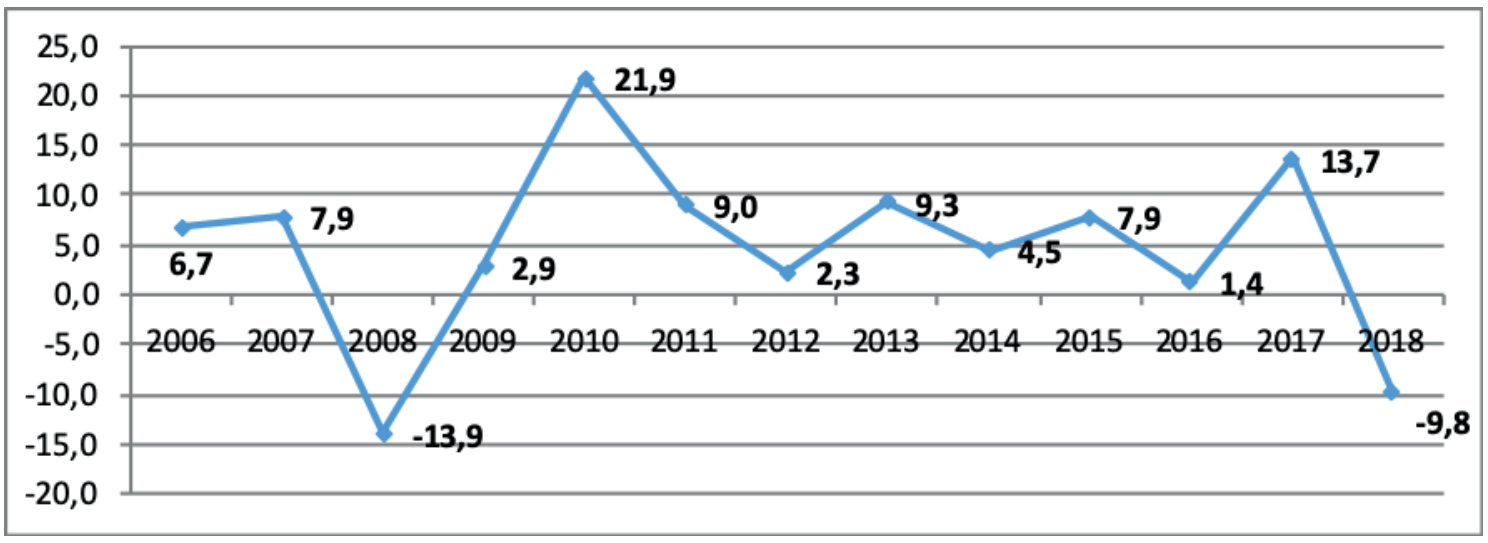

Source: Generated by the author with using seasonally adjusted TurkStat data

Figure 2 shows changes of seasonally adjusted industrial production index of Turkish economy from one December to the following December. While the production index increased approximately $6,7 \%$ in 2006 it started to decrease in 2007 . At the end of 2008 , as the effects of the crisis were observed, industrial production index decreased by $13,9 \%$ compared to the previous year. Production increased with the measures taken in 2009 and reached to its highest level in 2010 with $21,9 \%$. However, compared to the year before, industrial production index decreased in 2011, 2012, 2014 and 2016.

The instability in the industrial production index is in line with the economic growth. In 2017, industrial production significantly increased but this was short-lived. Industrial production decreased by $9,8 \%$ at the end of 2018. This contraction in industrial production is lower than the one in 2008.

The contraction in industrial production increases bankruptcy, liquidation and unpaid debts in the economy. According to the data of The Union of Chambers and Commodity Exchange of Turkey (TOBB), 23.596 companies were closed and 9.462 companies entered the liquidation process in September 2018 (TOBB, 2018: 19-20). The number of the firms applied for concordat was 401. In December, 1.566 companies entered the liquidation process while 3.960 companies were closed down (TOBB, https://www.tobb.org.tr/en/, Date Accessed: 21.03.2019). The continuously decrease in the industrial production index adversely affect both the unemployment data and foreign trade data.

Figure 3. Change Rates of Construction Cost Index Compared to the December of the Previous Year (\%)

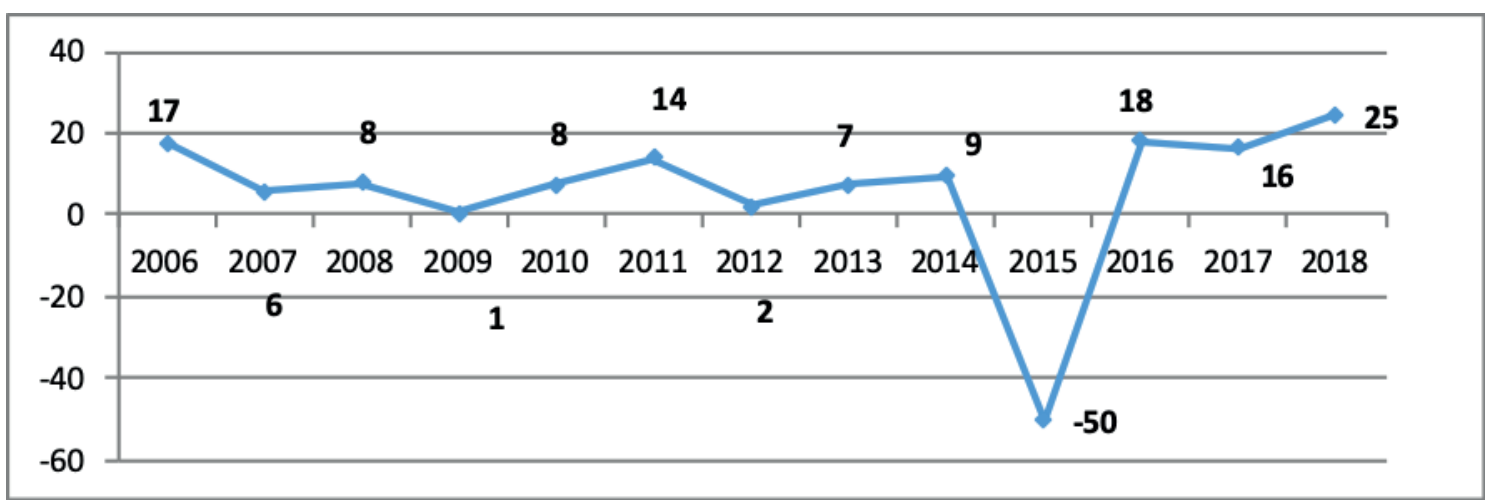

Source: Generated by the author using TurkStat data (2005 and 2015 are taken as base years) 
Figure 3 shows the change in the construction cost index of 2006-2018 compared to December of the previous year. Construction costs decreased by $50 \%$ in 2015 . The main reason for this significant decline is thought to be the change in the base year, because the costs have continued to increase in the following years. Costs increased 18\% in 2016, 16\% in 2017 and 25\% in 2018.

The increase in construction costs had a negative impact on the housing market. Housing sales increased by $4 \%$ in 2016 and 5\% in 2017 and decreased by 2,4\% in 2018 (TurkStat, https:// biruni.tuik.gov.tr/medas/?kn=73\&locale=en, Date Accessed: 21.03.2019). In order to prevent this decline, fiscal policy was brought to agenda. VAT rates were decreased from 18 percent to 8 percent in housing sales. In addition, the reduction of title deed fees from 4 percent to 3 percent was continued. However, the high interest rates and construction costs did not provide sufficient demand.

The instability in the economy affects many data. In this respect, it is seen that economic data are not independent from each other but affect each other. The decrease in the industrial production index lead to increase the number of close down firms and unemployment. The most important outcome of the increase in construction costs and decrease of industrial production index is seen in employment.

Figure 4. Change of Unemployment Rate Compared to Previous Year

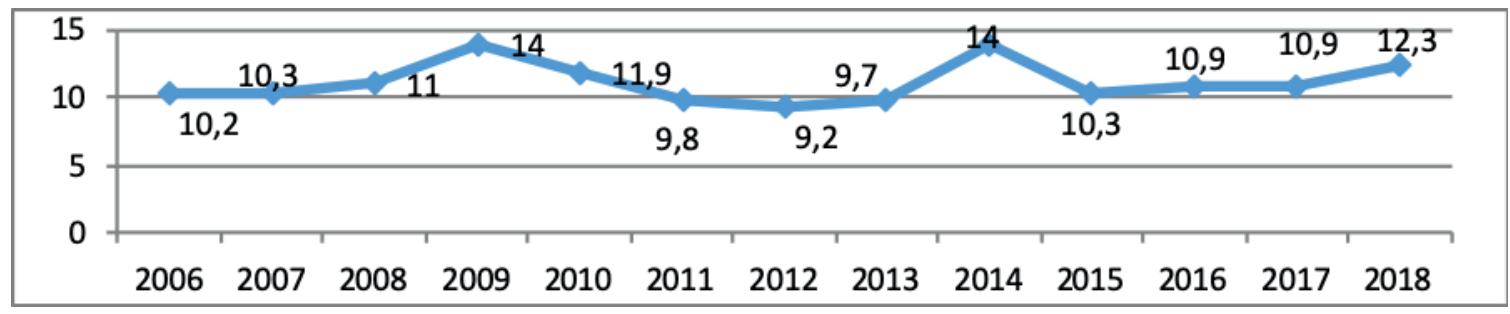

Source: Generated by the author using TurkStat data.

Figure 4 presents the change of unemployment rates compared to the one year before. The data contains information between 2006- 2018. The unemployment rate was $10 \%$ in 2006 and 2007. It increased to $11 \%$ in 2008 and $14 \%$ in 2009. In the following three years, it decreased gradually. It increased to $9,7 \%$ in 2013 . In 2014, It increased to $14 \%$ due to the contraction in the economy. It decreased to 10,3\% in 2015 while it increased to 12,3\% in 2016, 2017 and 2018. In fact, it has not reached the level it reached in 2009. Considering all of these developments, one can say there is a recession in the economy. Moreover, rising inflation has accompanied to this recession since 2016.

Inflation is an instantaneous and continuous rise in the general price level within six-month period. In developing countries continuous price increases over $6 \%$ is considered as inflation while this rate is $3 \%$ for developed countries. Moreover, inflation rate below $7 \%$ is considered as a moderate inflation, while two-or three-digit inflation rates are accepted as excessive inflation (Ulusoy, 2016: 186). 
Figure 5. CPI, \% Change Compared to December of Previous Year

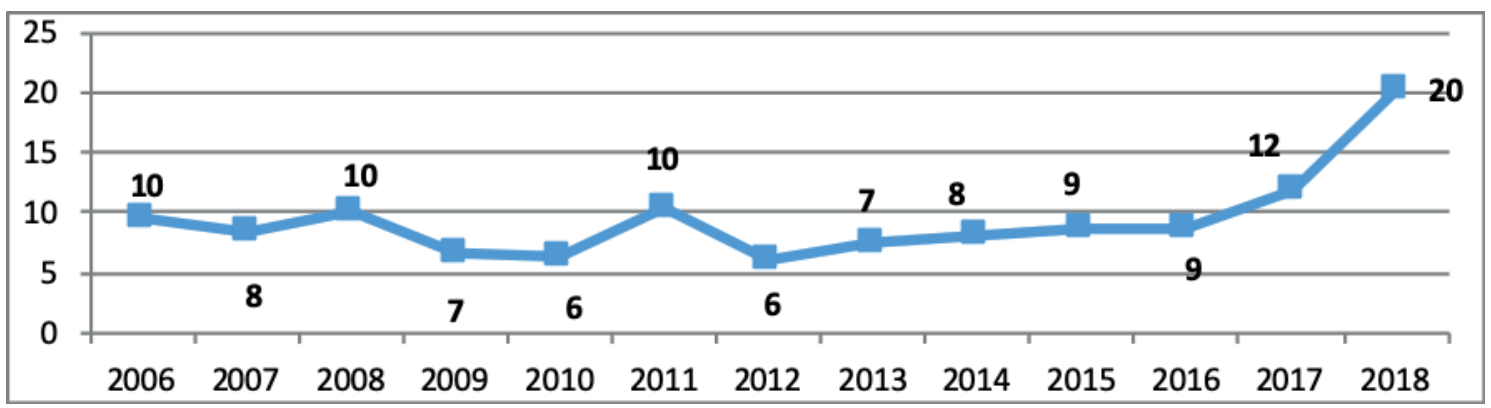

Source: Generated by the author using TurkStat data.

Figure 5 shows the yearly percentage change in consumer price index (CPI) and consist the data between 2006- 2018. Inflation rate has not decreased below $6 \%$ within the relevant period. Inflation reached to double-digit figures in 2017 which is higher compared to the period of 2008 crisis.

The decrease in consumption and investment expenditures in the economy leads to shortage of demand (TurkStat, http://tuik.gov.tr/HbGetir HTML. Do? Id = 30886, Date Accessed: 21.03.2019). Production decreases due to the lack of demand. Enterprises work with low capacity and employment increases (Ulusoy, 2016: 220). On the other hand, inflation adversely affects exports and triggers unemployment.

Turkish economy experiences slumpflation in 2018 where the economy contradicts with an excessive inflation (Eğilmez, http://www.mahfi egilmez.com/ 2019/03/turkiye-slumpflasyonagirdi.html, Date Accessed: 22.03.2019). It is difficult to fight with slumpflation.

Expansionary fiscal policies (increasing public expenditures, tax reductions) should be implemented in the fight against recession. Public expenditures should encourage private sector spending to prevent contraction in the economy. Moreover, by multiplier effect public spending will provide an expansion in the economy. Turkey implement SCT and VAT reductions to stimulate private sector spending. Budget expenditures were increased by $22,4 \%$ and accordingly public expenditures rises by TL 830 billion. The budget has given deficit (Ministry of Treasury and Finance, http://www.bumko.gov.tr/Eklenti/12349,aralik-2018-aylik-butce-gerceklesmelerirapo rupdf.pdf? 0, Data Accesed: 21.03.2019). Expansionary fiscal policy was applied but the desired outcome could not be obtained.

Contractionary fiscal policy should be implemented in the fight against inflation. In October 2018 , the inflation rate beat a record with a rate of $25,24 \%$. As a result, an anti-inflation program has introduced. As an outcome, inflation rate decreased to $21,62 \%$ in November and $20 \%$ in December. The main reason behind this is reduction of transportation costs by cheapen the oil prices.

Real sector data of Turkey shows the problems like high inflation, unemployment, economic downturn, decline of industrial production. The growth rate has not experienced a decline seen in 2008 yet. Industrial production index decreased by $7 \%$ compared to 2017 . However, it has not reached 2008-2009 level. The construction cost index increased highly (25\%) compared to 2008-2009. Inflation was doubled in the same period. These data show us the fact that Turkey 
experiences slumpflation. Expansionary policies should be implemented to increase demand until recovery. When recovery achieved, contractionary policies should be implemented. Economic problems should be identified on time and right policies should be implemented without delay. In addition, the success of the policies increases as compatibility with other policies increases.

\section{Conclusion}

As a result of globalization, the international flow of financial capital increased and crises multiplied. Turkish economy is also affected by the global crises. 2008 crisis that emerged in the US was reawaken Keynesian policies and social state. Turkey indirectly affected by the crisis and has implemented mainly expansionary fiscal policy. Thus, the economy started to recover by the end of 2009.

This study compares 2018 and 2008-2009 Turkish data in terms of the growth rate, inflation, industry production index, construction cost index, unemployment. The growth rate did not experience a similar decline as in 2008 crisis period. Industrial production index decreased by $7 \%$ compared to 2017. However, it has not reached 2008-2009 level. The construction cost index increased highly (25\%) compared to 2008-2009. Inflation is doubled and appeared as $20 \%$ in 2018. These data show us the fact that Turkey experiences slumpflation.

Both expansionary and contractionary policies must be implemented in order to fight with slumpflation. Public spending has increased through tax cuts for the recovery of Turkish economy. However, the demand has not reached the desired level. Expansionary fiscal policies should be continued and after demand reaches to the desired level contractionary policy should be applied. Fiscal policy should be implemented on time and be supported with other policies.

Probably monetary policies, anti-inflation measures, tax incentives, the new economic programs, increase in public savings will solve the problems but this will take time. The economic crisis is not experienced only in the real sector. The crisis occurred in the real sector appear as dead loans in the financial sector. Therefore, loan and financial sector data should be considered and evaluated.

\section{References}

Eğilmez, M. (2009). Küresel Finans Krizi Piyasa Sisteminin Eleştirisi, 4. Eds., İstanbul, Remzi Kitabevi.

Eğilmez, M. (2019). "Türkiye Ekonomisinde Gidişin Analizi", Kendime Yazılar, http://www. mahfiegilmez.com/2019/02/turkiye-ekonomisindeki-gidisin-analizi.html, (26.02.2019).

Eğilmez, M. (2019). "Türkiye Slumpflasyona Girdi", Kendime Yazılar, http://www.mahfiegilmez. com/2019/03/turkiye-slumpflasyona-girdi.html, (22.03.2019).

Kazgan, G. (2013). Türkiye Ekonomisinde Krizler (1929-2009), 4. Baskı, İstanbul Bilgi Üniversitesi Yayınları.

Krugman, P., Maurice O. \& Melitz, M. J., International Economics Theory \& Policy, Ninth Edition.

Piketty, T. (2018). Yirmi Birinci Yüzyılda Kapital, Çev. Koçak, H., İstanbul, Türkiye İş Bankası Kültür Yayınları. 
Ministry of Treasury and Finance. Döviz Kurları, http://www.bumko.gov.tr/TR,150/ doviz-kurlari. html, (21.03.2019).

Ministry of Treasury and Finance. (2018). Aylık Bütçe Gerçekleşmeleri Raporu 2018 Aralık, http:// www.bumko.gov.tr/Eklenti/12349,aralik-2018-aylik-butcegercek lesmeleriraporupdf.pdf?0 (21.03.2019).

T.C. Resmi Gazete. Bazı Varlıkların Milli Ekonomiye Kazandırılması Hakkında Kanun, 22 Kasım 2008, Sayı: 27062.

T.C. Resmi Gazete. Yatırımlarda Devlet Yardımları Hakkında Karar, 16 Temmuz 2009, Sayı: 27290.

T.C. Resmi Gazete. Türk Parası Kıymetini Koruma Hakkında 32 Sayılı Kararda Değişiklik Yapılmasına Dair Karar, 12 Eylül 2018, Sayı: 85.

TOBB. (2018). Kurulan/Kapanan Şirket Istatistikleri, https://www.tobb.org.tr/BilgiErisi mMudurlugu/Sayfalar/KurulanKapananSirketistatistikleri.php, (21.03.2019).

TurkStat. (2018). News Bulettin, http://tuik.gov.tr/OncekiHBArama.do, (22.02.2019).

TurkStat. (2018). Periodic Gross Domestic Product, IV. Quarter: October-December, 2018, http:// tuik.gov.tr/HbGetirHTML.do?id=30886, (21.03.2019).

TurkStat. (2018). Statistics, http://tuik.gov.tr/UstMenu.do?metod=temelist, (22.02.2019).

TÜSIAD. (2018). "2018 Yılına Girerken Türkiye ve Dünya Ekonomisi”, Ekonomik Araştrrmalar Bölümü, Ocak 2018, İstanbul.

Ulusoy, A. (2016). Maliye Politikası, Kocaeli, Umuttepe Yayınları.

Yılmaz, B. E. (2014). Türkiye'nin Değişmeyen Kaderi (Osmanlı'dan Günümüze 1854-2013) Borç Çıkmazı, 2. Baskı, İstanbul, Derin Yayınları. 